\title{
Pengaruh Disiplin Dan Kompensasi Terhadap Kinerja Pegawai Di Pusat Pendidikan Dan Pelatihan Pegawai Kementerian Pendidikan Dan Kebudayaan
}

\author{
Linda Suprihatin ${ }^{1}$, Gunarda ${ }^{2}$ \\ Dosen Fakultas Ekonomi Universitas Pamulang \\ Email : dosen00587@unpam.ac.id
}

\begin{abstract}
ABSTRAK
Tujuan penelitian ini adalah untuk mengetahui dan menelaah seberapa besar pengaruh disiplin dan kompensasi terhadap kinerja pegawai. Penelitian dilaksanakan di Pusat Pendidikan dan Pelatihan Kementerian Pendidikan dan Kebudayaan, dengan subjek penelitian pegawai Pusdiklat Kemendikbud yang berjumlah 30 orang.

Penelitian ini merupakan penelitian deskriptif korelasional yang bersifat meneliti hubungan antara variabel-variabel yang diteliti, sehingga akan diketahui seberapa besar pengaruh disiplin, dan kinerja terhadap kinerja pegwai di Pusdiklat Kemendikbud melalui pengujian hipotesis yang diajukan, sedangkan teknik analisis data yang digunakan adalah analisis korelasi product moment dengan taraf signifikansi 5\% dan analisis regresi ganda.

Hasil Penelitian menunjukkan bahwa : (1) Terdapat pengaruh yang positif dan signifikan antara disiplin terhadap kinerja pegawai ; (2) terdapat pengaruh yang positif dan signifikan antara kompetensi dengan kinerja pegawai; (3) terdapat pengaruh yang positif dan signifikan antara disiplin dan kompensasi secara bersama-sama terhadap kinerja pegawai ; (4) Nilai kontribusi variabel disiplin dengan kinerja pegawai berkontribusi sebesar 10,2\%; variabel kompensasi dengan kinerja pegawai berkontribusi sebesar 9,60\%; variabel disiplin dan kompensasi secara bersama berkontribusi $11,90 \%$.
\end{abstract}

Kata kunci: Disiplin, Kompensasi, dan Kinerja Pegawai. 


\section{PENDAHULUAN}

Pegawai merupakan salah satu asset terpenting di dalam organisasi. Oleh karenanya seorang Pegawai sebagai perencana dan pelaksana pembangunan perlu dibina dan dikembangkan, agar memiliki kemampuan, berdedikasi dan berdisiplin tinggi serta berprestasi dalam melaksanakan tugas dan kewajibannya, sehingga peranan pegawai akan semakin terasa penting, karena pada hakekatnya pegawai yang jadi pemikir, perencana dan pelaksana pembangunan melalui organisasi yang dijalankan dimana mereka bekerja untuk lebih berproduktif terhadap tugas-tugas yang dikerjakan. Sebagai pegawai juga dituntut untuk mempunyai sikap mental, tekad dan semangat, kedisiplinan serta memiliki kinerja yang tinggi agar apa yang dilaksanakan dalam tugas berjalan sesuai dengan rencana dan kebutuhan organisasi.

Tercapainya tujuan suatu lembaga atau organisasi tidak hanya tergantung pada peralatan modern, sarana dan prasarana yang lengkap, tetapi justru lebih tergantung pada manusia (pegawai) yang melaksanakan pekerjaan tersebut. Oleh karena itu pada lingkungan Pusat Pendidikan dan Pelatihan (Pusdiklat) Kementerian Pendidikan dan Kebudayaan (Kemendikbud), pegawai yang berkualitas adalah pegawai yang melaksanakan pekerjaannya dan mampu memberikan hasil kerja yang baik atau mempunyai disiplin yang tinggi, yang dibutuhkan oleh instansi untuk mencapai tujuan dan hasil produksi yang tinggi. Tingginya hasil kerja pegawai dipengaruhi oleh tingginya tingkat disiplin kerja yang dijalankan pegawai, apapun bentuk kegiatan tanpa ditunjang oleh disiplin kecenderungannya akan membawa dampak yang buruk.

Peraturan Pemerintah No.53/ 2010 tentang Disiplin PNS merupakan langkah awal untuk menciptakan aparatur yang profesional sebagai pengganti PP No. 30 Tahun 1980 yang bersifat umum.

Sanksi bagi pelanggar disiplin tentang ketentuan tidak masuk kerja, memberikan sanksi yang bervariasi bagi PNS yang melanggar disiplin. Sanksi tersebut adalah sebagai berikut:

1. Disiplin ringan, teguran tertulis tidak hadir selama 5 - 15 hari

2. Disiplin sedang, penundaan kenaikan pangkat/penurunan pangkat tidak hadir selama 21 30 hari

3. Disiplin berat, penurunan pangkat selama 3 tahun pemberhentian dengan atau tidak dengan hormat, tidak hadir selama 31 - 46 hari

Dari sanksi tersebut, upaya pendisiplinan pegawai, Pusdiklat Kemdikbud telah menggunakan mesin pencatat kehadiran yang dikenal dengan card finger. Dengan menggunakan mesin ini diharapkan kehadiran pegawai akan bisa lebih baik, disamping itu kehadiran pegawai mempengaruhi pemberian kompensasi (tunjangan kinerja), di Pusdiklat Kemendikbud yang telah diatur dalam Keputusan Menteri Pendidikan dan Kebudayaan Republik Indonesia Nomor 107 Tahun 2013 Tentang Tunjangan Kinerja Bagi Pegawai di Lingkungan 
Kementerian Pendidikan dan Kebudayaan

Dari keputusan tersebut disinilah disiplin dan kompensasi merupakan hal yang penting dalam menunjang kinerja. Kompensasi finansial yang diberikan berupa gaji uang makan dan tunjangan kinerja. Dalam pada ini kompensasi yang berada di luar gaji, yaitu uang makan dan tunjangan kinerja. Tunjangan kinerja terkait dengan kedisiplinan pegawai dalam memasuki kerja, apabila pegawai tidak masuk kerja dalam 1 (satu) hari maka ia dikenakan pemotongan terhadap tunjangan kinerja 3\%, ketentuan tersebut mengacu pada Keputusan Menteri Pendidikan dan Kebudayaan Republik Indonesia Nomor 107 Tahun 2013 Tentang Tunjangan Kinerja Bagi Pegawai di Lingkungan Kementerian Pendidikan dan Kebudayaan pada pasal 6, bahwa hari kerja mulai Senin sampai dengan Hari Jumat dengan jumlah jam kerja sebanyak 37,5 (tiga puluh tujuh koma lima).

Pentingnya kompensasi dalam melaksanakan tugas di unit kerja merupakan salah satu tugas utama aparatur pemerintah yang harus dipahami dan dilaksanakan sepenuh hati, serta akuntabel. Oleh karenanya Pusdiklat Pegawai perlu menyusun rencana kerja dan memperhatikan berbagai hal penting dan terkait erat dengan kinerja yang dihasilkan hingga tercipta hasil kerja yang lebih baik. Hasil kerja yang baik merupakan perwujudan dari tujuan instansi yang perlu ditanamkan pada sikap pegawai. Sedangkan pada pelaksanaannya Pusdiklat Pegawai Kemdikbud merupakan suatu instansi yang bergerak di bidang penyelenggaraan diklat sedangkan pesertanya dari berbagai disiplin ilmu, dimana keberhasilan pelaksanaan tugas dan tanggung jawab dalam instansi tergantung pada pegawai

yang memiliki wawasan kedepan, memiliki kompetensi yang tinggi dan lingkungan kerja yang kondusif agar tugas dapat dilaksanakan dengan baik, tetapi pada kenyataannya kehadiran pegawai dilihat dari kehadiran pada tahun 2017 antara bulan Juli sampai dengan Desember sebagai berikut.

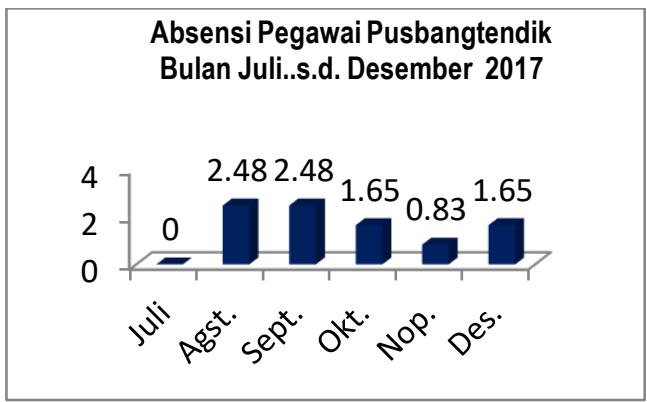

Gambar diatas, menunjukkan hasil rekapitulasi kehadiran pegawai selama enam bulan periode Juli s.d. Desember 2017. Pegawai yang tidak masuk kerja dengan tanpa alasan tertinggi berada pada bulan Agustus dan September sedangkan yang terendah adalah pada bulan Juli, sehingga secara rata-rata remunerasi yang diberikan pegawai belum mencapai secara optimal, sehingga kompensasi pegawai yang bersangkutan akan dikenakan pemotongan terhadap tunjangan kerja, sebesar 3\% dari kompensasi yang diterima. 
Tabel Remunerasi PNS Tunjangan Kinerja Berdasarkan Grade

Tahun 2017

\begin{tabular}{|l|l|r|}
\hline Grade & $\begin{array}{c}\text { Kelas } \\
\text { Jabatan }\end{array}$ & $\begin{array}{c}\text { Tunjangan } \\
\text { Kinerja } \\
(\mathrm{Rp})\end{array}$ \\
\hline 1 & 17 & 25.168 .000 \\
\hline 2 & 16 & 18.370 .300 \\
\hline 3 & 15 & 13.409 .500 \\
\hline 4 & 14 & 9.787 .700 \\
\hline 5 & 13 & 7.829 .900 \\
\hline 6 & 12 & 6.264 .700 \\
\hline 7 & 11 & 5.011 .500 \\
\hline 8 & 10 & 4.357 .600 \\
\hline 9 & 9 & 3.789 .500 \\
\hline 10 & 8 & 3.295 .500 \\
\hline 11 & 7 & 2.995 .200 \\
\hline 12 & 6 & 2.723 .500 \\
\hline 13 & 5 & 2.475 .200 \\
\hline 14 & 4 & 2.358 .200 \\
\hline 15 & 3 & 2.245 .100 \\
\hline 16 & 2 & 2.138 .500 \\
\hline 17 & 1 & 2.031 .900 \\
\hline
\end{tabular}

Berdasarkan tabel di atas, kinerja pegawai seyogyanya dipandang sebagai salah satu unsur yang dapat mencapai hasil kerja yang lebih baik juga dapat dicapai dengan perbuatan yang dibebankan secara optimal yang terdorong oleh keinginan sendiri, tekun, serta meningkatnya kompetensi pegawai yang tinggi sehingga dapat tercapai tujuan Instansi di bawah arahan dan kepemimpinan yang dapat menciptakan suasana kondusif terhadap lingkungan kerja lembaga tersebut.

Untuk itu upaya pimpinan dalam dalam menicptakan remunerasi, kompetensi dan lingkungan kerja yang kondusif belum cukup menjamin bagi seorang pegawai dapat mencapai tingkat kinerja yang optimal. Remunarasi dalam bentuk konpensasi menurut Rivai merupakan sesuatu yang diterima pegawai sebagai pengganti kontribusi jasa pada unit kerja (2011:357). Pemberian kompensasi merupakan salah satu pelaksanaan fungsi manajemen sumber daya manusia yang berhubungan dengan semua jenis pemberian penghargaan individual sebagai pertukaran dalam melakukan tugas keorganisasian. Kompensasi merupakan biaya utama atas keahlian atau pekerjaan dan kesetiaan dalam unit kerja dan kompensasi menjadi alasan utama kebanyakan orang mencari pekerjaan, sedangkan kompetensi merupakan sikap pegawai yang harus dimiliki agar mereka dapat bekerja dengan lebih baik lagi, hal tersebut juga perlu ditunjang dengan menciptakan lingkungan kerja yang kondusif, dan perlu adanya pihak yang memiliki kekuasaan yang lebih besar, sehingga mampu mempengaruhi perilaku pegawai dalam berkinerja.

Dengan memperhatikan keterkaitan yang terjadi antara disiplin dan kompensasi terhadap kinerja pegawai, maka perlu adanya pengkajian dan pembuktian baik secara teoretik maupun empirik terhadap keterkaitan hal-hal tersebut di atas. Hasil pengkajian ini selanjutnya dapat dijadikan sebagai salah satu bukti pembenaran dan pengembangan lebih lanjut, terhadap pengaruh disiplin dan kompensasi terhadap kinerja pegawai.

Disiplin kerja adalah kesadaran dan kerelaan seseorang dalam menaati semua peraturan perusahaan dan 
norma-norma sosial yang berlaku, Malayu Hasibuan (2006:444). Kemudian Veithzal Rivai (2011:825) bahwa Disiplin kerja adalah suatu alat yang dipergunakan para manajer untuk berkomunikasi dengan karyawan agar mereka bersedia untuk mengubah suatu perilaku serta sebagai suatu upaya untuk meningkatkan kesadaran dan kesediaan seorang dalam memenuhi segala peraturan perusahaan.

Semua organisasi didalamnya memiliki sumber-sumber daya yang harus dimanfaatkan, diperbaiki dan ditingkatkan untuk mencapai tingkat operasional yang efektif. Untuk melihat tercapai atau tidaknya tujuan organisasi dapat diukur dari cara kerja para pegawai dalam melakukan aktivitasnya, agar para pegawai tersebut dapat mencapai tujuan kerja sesuai dengan standar waktu yang telah ditentukan dalam organisasi perlu adanya kompensasi kepada pegawai, karena dengan adanya kompensasi yang merupakan salah satu tingkat kesejahteraan yang diberikan kepada pegawai atas pelaksanaan tugas diharapkan akan tumbuh kegairahan dan motivasi kerja yang tinggi untuk mencapai tujuan organisasi. Kompensasi merupakan balas jasa yang diberikan oleh organisasi/unit kerja kepada pegawai, yang dapat bersifat finansial maupun non finansial, pada periode yang tetap. Sistem kompensasi yang baik akan mampu memberikan kepuasan bagi pegawai dan memungkinkan unit kerja organisasi memperoleh, mempekerjakan, dan mempertahankan pegawai. Kompensasi adalah semua pendapatan yang berbentuk uang, barang langsung atau tidak langsung yang diterima pegawai sebagai imbalan atas jasa yang diberikan oleh lembaga/perusahaan. Malayu S.P. Hasibuan (2006 : 118) Sedangkan Hadari Nawawi (2003 : 315), Kompensasi adalah penghargaan atau ganjaran yang diberikan pada para pegawai yang telah memberikan kontribusi kepada organisasi dalam mewujudkan tujuannya, melalui kegiatan yang disebut bekerja. Dengan demikian kompensasi adalah pemberian jasa kepada pegawai atas pengabdiannya yang ditunjukan dari hasil kerja yang memiliki ciri-ciri mencakup indikator sebagai berikut : (1) prestasi kerja, (2) Imbalan ekstrinsik, dan (3) Imbalan intrinsik. Kompensasi merupakan balas jasa yang diberikan oleh organisasi atau unit kerja kepada pegawai, yang dapat bersifat finansial maupun non finansial, pada periode yang tetap. Sistem kompensasi yang baik akan mampu memberikan kepuasan bagi pegawai dan memungkinkan unit kerja memperoleh, mempekerjakan, dan mempertahankan pegawai. Sedangkan kinerja merupakan hasil kerja yang ditunjukan oleh pegawai yang dapat dipengaruhi oleh konpensasi. Dengan demikian apabila pelaksanaan kompensasi dapat dilaksanakan dengan baik kepada pegawai, maka kinerja pegawai akan baik pula. Kinerja menurut Hendrawan adalah suatu konstruk multidimensional yang sangat kompleks, dengan banyak perbedaan dalam arti tergantung pada siapa yang sedang mengevaluasi, bagaimana dievaluasi, dan aspek apa yang dievaluasi (2006:12).

Perkembangan suatu instansi baik dilihat dari beban tugas, perkembangan teknologi, dan metode 
kerja yang baru, perlu mendapat perhatian dan respon dari instansi. Oleh sebab itu pemberdayaan pegawai yang akan diberi wewenang dan tanggung jawab, perlu dibekali dengan pengetahuan dan keterampilan yang memadai serta pemberian kompensasi serta penetapan disiplin kerja yang tepat untuk tercapainya tujuan utama instansi, serta meningkatkan kinerja setiap pegawai yang ada di Pusdiklat Kemdikbud. Dengan demikian disiplin dan kompensasi berpengaruh terhadap kinerja pegawai.

\section{METODE PENELITIAN}

Penelitian ini dilaksanakan menggunakan metode survei dengan pendekatan kuantitatif. Metode survei digunakan pada tahap proses pengumpulan data. Data dalam penelitian ini dikumpulkan dengan cara mengambil sampel dari keseluruhan anggota populasi. Pendekatan kuantitatif dilakukan untuk menguji hipotesis penelitian. Proses pengujian hipotesis dilakukan untuk menjawab pertanyaan yang diajukan dalam rumusan masalah penelitian. Hipotesis penelitian diuji untuk mengetahui pengaruh antar variabel penelitian dengan menggunakan teknik analisis jalur. Konstelasi masalah yang menggambarkan keterkaitan antara variabel penelitian ditunjukkan pada gambar sebagai berikut:

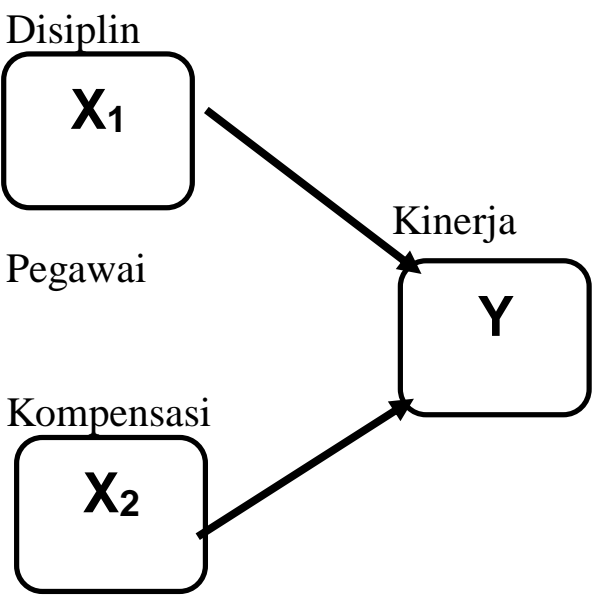

$$
\begin{aligned}
& \mathrm{X}_{1}=\text { Disiplin (variabel bebas 1) } \\
& \mathrm{X}_{2}=\text { Kompensasi (variabel bebas 2) } \\
& \mathrm{Y}=\text { Kinerja (variabel terikat) } \\
& \varepsilon \quad=\text { Variabel lain yang } \\
& \text { berpengaruh tapi tidak diteliti } \\
& \text { (epsilon) }
\end{aligned}
$$

$\mathrm{rX}_{1} \mathrm{y}=$ Besarnya pengaruh variabel $\mathrm{X}_{1}$ terhadap variabel $\mathrm{Y}$ $\mathrm{rX}_{2} \mathrm{y}=$ Besarnya pengaruh variabel $\mathrm{X}_{2}$ terhadap variabel $\mathrm{Y}$

$\mathrm{RX}_{1} \mathrm{X}_{2} \mathrm{y}=$ Besarnya pengaruh variabel $X_{1}$ dan variabel $X_{2}$ secara bersama-sama terhadap variabel $\mathrm{Y}$

\section{HASIL DAN PEMBAHASAN}

Data dalam penelitian ini mencakup uraian tentang gambaran umum dari setiap variabel penelitian yang terdiri dari: Disiplin (X1), dan kompensasi (X2), terhadap Kinerja Pegawai (Y). Deskripsi data lebih rinci dari masing masing variabel tersebut, mencakup: rerata, modus, median, variansi, dan simpangan baku, serta distribusi frekuensi disertai histogram.

Rentang skor teoretik variabel Disiplin, berkisar antara $44-134$. Hasil penelitian terhadap variabel ini, menghasilkan rentang skor empirik sebesar 90. Rentang skor sebesar ini, merupakan selisih antara skor minimum sebesar 44 dengan skor maksimum sebesar 134. Sementara 
itu besarnya: modus 78,32, median 79,41 , dan rerata 87,80 , dan simpangan baku sebesar 18,60. Berkaitan dengan sebaran frekuensi skor disiplin para responden dapat diklasifikasikan menjadi: 3,33\% sangat rendah, 6,673\% rendah, $13,33 \%$ cukup tinggi, $23,33 \%$ tinggi, dan $36,67 \%$ sangat tinggi. Sebaran frekuensi skor seperti ini, menunjukan bentuk distribusi normal.

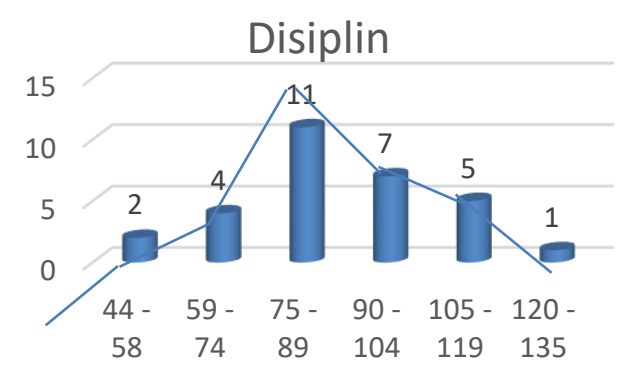

Sedangkan untuk rentang skor variabel kompensasi, berkisar antara 113 - 61. Hasil pengukuran terhadap variabel ini, menghasilkan rentang skor empirik sebesar 52. Rentang skor sebesar ini, merupakan selisih antar skor minimum sebesar 61 dengan skor maksimum sebesar 113. Sementara itu besarnya: modus 107,83 , median 110,95 , dan rerata 90,20, dan simpangan baku sebesar 18,97, sedangkan untuk sebaran frekuensi data kompensasi dapat diklasifikasikan menjadi nilai $3,33 \%$ sangat rendah, dan tertinggi $36,67 \%$. Sebaran frekuensi data seperti ini, menunjukan bentuk distribusi normal

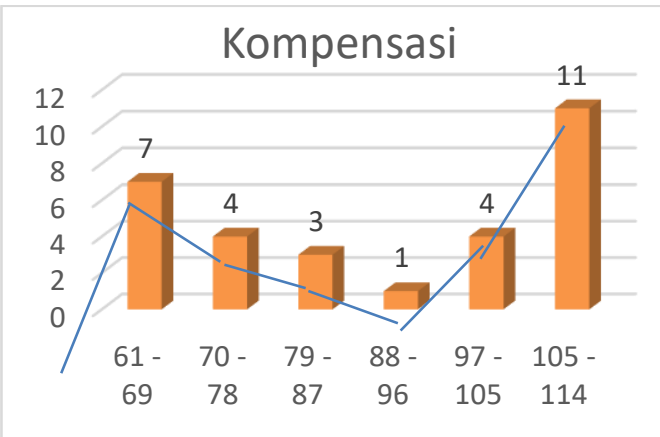

Untuk variabel terikat, yaitu kinerja pegawai memiliki rentang skor variabel kinerja pegawai, berkisar antara $72-118$. Hasil penelitian terhadap variabel ini, menghasilkan rentang skor empirik sebesar 46. Rentang skor sebesar ini, merupakan selisih antara skor minimum sebesar 72 dengan skor maksimum sebesar 118. Sementara itu besarnya: modus 100,95, median 96,5, dan simpangan baku sebesar 9,59. Dengan demikian sebaran frekuensi skor pelayanan, bahwa responden dapat diklasifikasikan menjadi: nilai terendah $3,33 \%$, dan tertinggi $40,00 \%$. Sebaran frekuensi skor seperti ini, menunjukan bentuk distribusi normal.

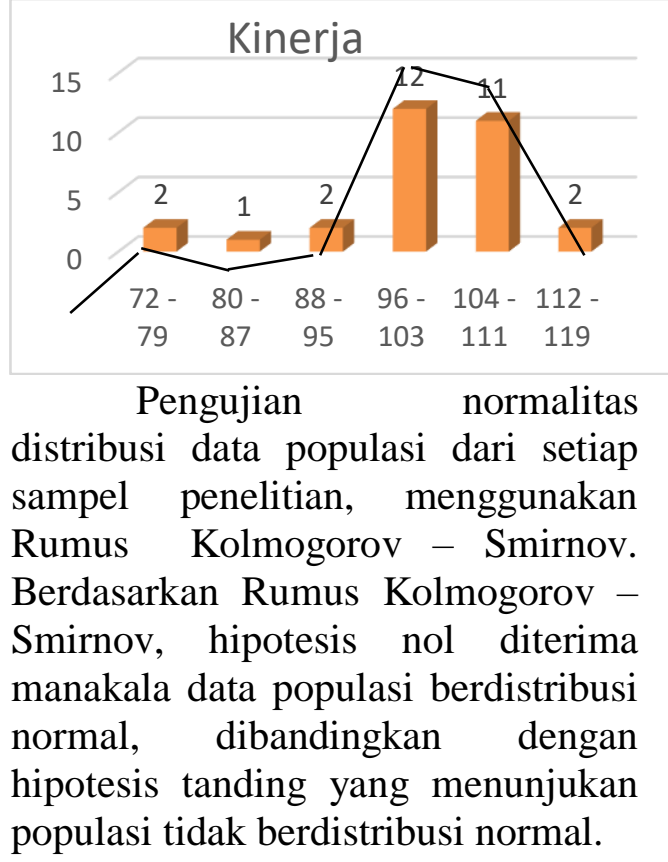


One-Sample Kolmogorov-Smirnov Test

\begin{tabular}{|cc|c|c|}
\hline & & Skor & Skor \\
& & Y & X1 \\
\hline & & 89 & 89 \\
Normal & Mean & 96.71 & 104.1 \\
Parameters $^{\mathrm{a}}$ & Std. & 12.72 & 10.22 \\
& Deviation & 5 & 8 \\
Most & Absolute & .202 & .114 \\
Extreme & Positive & .114 & .059 \\
Differences & Negative & -.202 & -.114 \\
Kolmogorov-Smirnov Z & 1.908 & 1.071 \\
Asymp. Sig. (2-tailed) & .001 & .201 \\
\hline
\end{tabular}

a. Test distribution is Normal. b.

One-Sample KolmogorovSmirnov Test

\begin{tabular}{|c|c|c|c|c|}
\hline & & $\begin{array}{c}\text { Skor } \\
\text { Y }\end{array}$ & $\begin{array}{c}\text { Skor } \\
\text { X1 }\end{array}$ & $\begin{array}{c}\text { Skor } \\
\text { X2 }\end{array}$ \\
\hline $\mathrm{N}$ & & 89 & 89 & 89 \\
\hline Normal & Mean & 96.7 & 104. & 99.8 \\
\hline Paramete & & & 15 & 7 \\
\hline $\mathrm{rs}^{\mathrm{a}}$ & Std. & 12.7 & 10.2 & 16.1 \\
\hline & $\begin{array}{l}\text { Deviati } \\
\text { on }\end{array}$ & 25 & 28 & 51 \\
\hline Most $\quad A$ & Absolut & 202 & 114 & 142 \\
\hline Extreme e & e & & & \\
\hline $\mid \begin{array}{ll}\text { Differenc } & \mathrm{P} \\
\mathrm{es} & \mathrm{e}\end{array}$ & $\begin{array}{l}\text { Positiv } \\
\mathrm{e}\end{array}$ & .114 & .059 & .099 \\
\hline & $\begin{array}{l}\text { Negativ } \\
\mathrm{e}\end{array}$ & -.202 & -.114 & -.142 \\
\hline Kolmogoro & ov- & 1.90 & 1.07 & 1.34 \\
\hline Smirnov Z & & & & 1 \\
\hline $\begin{array}{l}\text { Asymp. Sig } \\
\text { tailed) }\end{array}$ & ig. (2- & .001 & .201 & .055 \\
\hline
\end{tabular}

a. Test distribution is Normal.

Secara statistik hal tersebut dituliskan sebagai berikut: $\mathrm{H}_{0}$ : $(\mathrm{Y}-$ $\hat{\mathrm{Y}}$ ) berdistribusi normal, melawan $\mathrm{H}_{1}$ :
$(\mathrm{Y}-\hat{\mathrm{Y}})$ tidak berdistribusi normal. Kriteria dalam pengujian ini adalah menerima hipotesis nol, jika penyimpangan terbesar memiliki kemungkinan sama atau kurang dibandingkan dengan harga kritis pada alpha 0,05 .

Hasil pengujian statistik One Sample Kolmogorov Smirnov menunjukkan besarnya Kolmogorov Smirnov untuk variable kinerja terhadap disiplin adalah 1.071 dan tidak signifikan pada 0.05 karena Asymp. Sig. (2-tailed) > 0.05. Berdasarkan penjelasan tersebut dapat disimpulkan bahwa data variable disiplin berdistribusi normal atau memenuhi syarat uji normalitas. Hasil perhitungan galat taksir regresi pelayanan (Y) terhadap kinerja pegawai melalui uji statistik One Sample Kolmogorov Smirnov menunjukkan bahwa beasrnya Kolmogorov Smirnov untuk variable kinerja terhadap kompensasi adalah 1.341 dan tidak signifikan pada 0.05 karena Asymp. Sig. (2-tailed) >0.05. Berdasarkan penjelasan tersebut dapat disimpulkan bahwa variabel kinerja terhadap pelayanan berdistribusi normal atau memenuhi syarat uji normalitas

Uji Multikolinearitas salah satunya dapat dilihat dari nilai tolerance dan lawannya variance inflation factor (VIF). Nilai cut off yang umum dipakai untuk menunjukkan adanya multikolinearitas adalah nilai tolerance $<0.10$ atau sama dengan nilai VIF $>10$. Hasil pengujian yang diperoleh menunjukkan nilai-nilai tolerance untuk semua variabel independen di atas 0.10 dan nilai VIF untuk semua variabel independen di bawah 10 , yaitu 2,759 . Hal ini sesuai 
dengan syarat tidak terjadinya multikolinearitas, sehingga semua variabel independen tersebut layak digunakan untuk variabel prediktor. Dari hasil uji multikorelitas berikut ini, menguraikan secara berturut-turut pengujian hipotesis masing-masing hubungan antarvariabel, meliputi pengujian hubungan: sederhana, jamak, dan parsial. Di samping itu, membahas juga tentang: persamaan regresi, koefisien korelasi parsial dan determinasi.

1. Hipotesis antara disiplin dan kinerja pegawai.

Hasil pengolahan data dengan menggunakan software SPSS 16 menunjukkan bahwa masingmasing variabel memiliki pengaruh yang signifikan. Masing-masing hasil uji signifikansi adalah untuk disiplin $0,010<0,050$ atau hasil uji $\mathrm{t}$ dengan $\mathrm{t}$ hitung 3,909 > dari $\mathrm{t}$ tabel 2,759 menunjukkan bahwa terdapat pengaruh positif antara disiplin terhadap kinerja pegawai. Besarnya pengaruh disiplin terhadap kinerja sebesar $22,97 \%$ merupakan hasil dari perkalian nilai Beta dan Zeroorder yaitu 0,086 × $0,709=$ $0,0609(6,09 \%)$.

Hasil uji signifikansi untuk disiplin terhadap kinerja pegawai adalah $0.000<0,050$ dan hasil uji $\mathrm{t}$ menunjukkan bahwa $\mathrm{t}$ hitung 3,909> dari $t$ tabel 2,759 menggambarkan terdapat pengaruh positif antara disiplin terhadap kinerja. Besarnya pengaruh disiplin terhadap pelayanan sebesar $6,09 \%$. Hal ini berarti bahwa, 6,09\% variasi kinerja dapat dijelaskan dengan disiplin melalui persamaan regresi $\hat{\mathrm{Y}}=24,212+0,107 \mathrm{X}_{1}$. Sehubungan dengan itu, pengujian tingkat signifikansi dapat dilihat pada tabel 4. dalam bentuk coefisients berikut ini

2. Hipotesis kedua penelitian ini adalah, terdapat pengaruh positif antara Kinerja pegawai $\left(\mathrm{X}_{2}\right)$ dengan pelayanan (Y). Hasil perhitungan yang didapat adalah untuk kinerja $0,000<0,050$ atau hasil uji t dengan t hitung 8,277 > dari t tabel 2,759 menunjukkan bahwa terdapat pengaruh positif antara kinerja terhadap pelayanan. Besarnya pengaruh disiplin terhadap pelayanan sebesar 28,29\% merupakan hasil dari perkalian nilai Beta dan Zero-order yaitu $0,780 \times 0,849=$ $0,6622(66,22 \%)$.

Hasil uji signifikansi untuk disiplin terhadap kinerja adalah $0.000<0,050$ dan hasil uji $\mathrm{t}$ menunjukkan bahwa $\mathrm{t}$ hitung $8,277>$ dari $t$ tabel 2,759 menggambarkan terdapat pengaruhn positif antara kompensasi terhadap kinerja. Besarnya pengaruh kompensasi terhadap kinerja pegawi sebesar $66,22 \%$. Hal ini berarti bahwa, $66,22 \%$ variasi kinerja pegawai dapat dijelaskan dengan kompensasi melalui persamaan regresi $\hat{Y}=24,212+0,615 X_{1}$

3. Hipotesis ketiga penelitian ini adalah, terdapat pengaruh disiplin $\left(\mathrm{X}_{1}\right)$, dan kompensasi $\left(\mathrm{X}_{2}\right)$ secara bersama-sama terhadap kinerja pegawai (Y). Hasil perhitungan terhadap hubungan jamak tersebut, membentuk persamaan regresi jamak untuk hubungan semua variabel sebagai berikut. Untuk 
persamaan $\mathrm{Y}$ dari penelitian ini dapat dilihat dari kolom Unstandardized Coefficient B. hasil pengolahan data menggunakan SPSS 16 menunjukkan bahwa: persamaan regresinya adalah $\mathrm{Y}=$ $24.212+0,107 \mathrm{X}_{1}+0,615 \mathrm{X}_{2}$.

Hasil perhitungan dapat diketahui bahwa nilai $\mathrm{R}$ diperoleh 0,850 , sedangkan Nilai R Square diperoleh sebesar 0.723 . Hal ini berarti bahwa hanya $72,30 \%$ variabel pelayanan dapat dijelaskan oleh disiplin dan kinerja pegawai. Sedangkan sisanya, $27.70 \%$ dijelaskan oleh variabel-variabel lain di luar penelitian. Standard Error of the Estimate sebesar 6,775.

Rumus diatas menunjukkan bahwa besarnya pelayanan apabila tidak dipengaruhi disiplin dan kinerja pegawai adalah sebesar 24,212 satuan. Rumus tersebut menunjukkan pula apabila disiplin dan kinerja dinaikkan satu satuan akan meningkatkan disiplin 10,70\% $(0,107)$ dan kinerja $61,50(0,615)$.

Dari hasil hipotesis menunjukkan bahwa nilai $\mathrm{R}^{2}$ sebesar 0,723 atau $72,30 \%$, hal tersebut menggambarkan bahwa sumbangan disiplin dan kompensasi terhadap naik atau turunnya kinerja pegawai adalah $72,30 \%$ dan sisanya sebesar $27,70 \%$ merupakan sumbangan dari variabel lain yaitu kepemimpinan, kompetensi, kompensasi, kepuasan kerja, pelatihan, yang tidak dimasukkan dalam model yang diajukan dalam penelitian.

Uji hipotesis simultan dilakukan dengan membandingkan nilai $F$ hitung dengan nilai $F$ tabel. Nilai $F$ hitung dapat dilihat dari hasil pengolahan data bagian ANOVA. Nilai $F$ tabel dengan tingkat signifikan 5\% dan degrees offreedom (df) dengan $\mathrm{dk}$ pembilang $2 \mathrm{dan} \mathrm{dk}$ penyebut 86 adalah sebesar 14,211. Hasil pengolahan data diketahui bahwa nila $\mathrm{F}$ hitung sebesar 14,211 dan nilai $\mathrm{F}$ hitung tersebut lebih besar dari $\mathrm{F}$ tabel. Dari hasil uji hipotesis tersebut maka keputusan yang diambil adalah menolak $\mathrm{H}_{0}$ dan $\mathrm{H}_{1}$ diterima (hipotesis penelitian), artinya secara bersama-sama disiplin dan kompensasi secara bersama-sama mempunyai pengaruh yang signifikan terhadap kinerja pegawai di Pusdiklat Kemendikbud. Uji hipotesis simultan ini, untuk mengetahui terima atau menolaknya hipotesis, yang kemudian dilanjutkan dengan membandingkan nilai thitung dengan nilai $t$ tabel.Nilai thitung dapat dilihat pada hasil pengolahan data bagian Coefficient. Untuk memperoleh nilai t tabel, dapat dilihat dari tabel $T$ Student, yaitu pada degrees of freedom (df) sebesar 27 (jumlah data dikurangi jumlah variabel) dan pada signifikansi 5\% maka nilai t tabel adalah $1,160 . \quad$ Dengan membandingkan nilai $\mathrm{t}$ hitung dan $\mathrm{t}$ tabel maka dapat disimpulkan:

a. Variabel disiplin dengan t hitung $>$ dari t tabel atau 3,9095 > 2,759 maka $\mathrm{H}_{0}$ ditolak dan $\mathrm{H}_{1}$ diterima (hipotesis penelitian) diterima, artinya disiplin mempunyai pengaruh yang signifikan terhadap kinerja pegawai.

b. Variabel Kinerja dengan t hitung > dari $\mathrm{t}$ tabel atau 8,277>2,759 maka $\mathrm{H}_{0}$ ditolak dan $\mathrm{H}_{1}$ diterima (hipotesis penelitian) diterima, artinya kompensasi mempunyai pengaruh yang signifikan terhadap kinerja pegawai.

Dengan demikian persamaan garis regresi menggunakan metode kuadrat 
terkecil (least square method) yang didapat aaalah $\hat{\mathbf{Y}}=\mathbf{2 4 . 2 1 2}+\mathbf{0 . 1 0 7 \mathrm { X } _ { 1 }}$

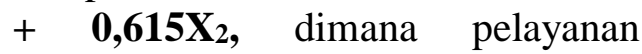
dipengaruhi oleh disiplin dan kinerja pegawai pada taraf signifikan 0,002 yang lebih rendah dari pada 0.05 . Dengan demikian dapat dikatakan bahwa Hipotesis Ha Diterima.

\section{KESIMPULAN}

Berdasarkan hasil penelitian yang tercakup dalam penelitian ini, dapat dirumuskan temuan penelitian sebagai berikut, terdapat pengaruh yang positif dan signifikan antara disiplin dan kinerja terhadap pelayanan, baik secara sendiri-sendiri maupun secara bersama-sama. Dari hasil temuan, dapat disimpulkan sebagai berikut:

Pertama; berdasarkan hasil penelitian ini bahwa terdapat pengaruh yang positif antara disiplin dan kompensasi di Pusdiklat Kemdikbud. Hal ini didasarkan dari bukti koefisien korelasi antara disiplin dan kinerja, yaitu sebesar 0,0609 dan uji t dengan thitung 3,909 $>$ dari t tabel 2,759, dan koefisien korelasi dengan kontribusi 6,09\%. Oleh sebab itu semakin tinggi disiplin, maka berpengaruh positif terhadap peningkatan kinerja pegawai. Dengan demikian, peningkatan disiplin perlu dilakukan secara berkelanjutan, sistematis, dan sungguh-sungguh.

Kedua; pengaruh yang positif ini mengindikasikan bahwa kompensasi $\mathrm{v}$ terhadap kinerja mempunyai pengaruh yang cukup besar, yaitu 0,6622 dengan besar kontribusi adalah 28,29\% lebih besar dari displin, dan uji t sebesar 8,277 > dari $t$ tabel 2,759, hal ini menunjukkan bahwa kompensasi memiliki pengaruh cukup besar terhadap kinerja. Oleh sebab itu semakin tinggi kompensasi, maka akan semakin tinggi pula kinerjapegawai. Sehingga peningkatan kompensasi ini, perlu dilakukan secara berkelanjutan, sistematis, dan sungguh-sungguh dari pegawai yang bersangkutan.

Ketiga disiplin dan kompensasi terhadap kinerja secara bersama-sama memiliki koefisien korelasi sebesar 0,850, sedangkan Nilai R Square diperoleh sebesar 0.723 . Hal ini berarti bahwa hanya $72,30 \%$ variabel kinerja pegawai dapat dijelaskan oleh disiplin dan kompensasi. Sedangkan sisanya, $27.70 \%$ dijelaskan oleh variabelvariabel lain di luar penelitian. Standard Error of the Estimate sebesar 6.775. Dengan demikian pkinerja, dapat dilakukan dengan meningkatkan disiplin dan kompensasi secara berkelanjutan, sistematis, dan sungguh-sungguh.

\section{DAFTAR PUSTAKA}

Tika, Moh. Pabundu. 2010. Budaya Organisasi dan Peningkatan Kinerja, Jakarta: Bumi Aksara.

Mangkunegara, AA Anwar Prabu. 2007. Evaluasi Kinerja SDM. Bandung: Refika Aditama.

Edy Sutrisno, 2010, Manajemen Sumber Daya Manusia, Cetakan Ketiga, Kencana Prenada Media Group, Jakarta

Arief Djamaludin., 2006, Diktat Kuliah Persiapan dan Seleksi Dalam MSDM. Palembang : Program Magister Manajemen UTP. 
A.W Widjaya, 2008, Teknik Memimpin Pegawai dan Pekerjaan, Jakarta: Haji Masagung.

Edy Sutrisno, 2010, Manajemen Sumber Daya Manusia, Cetakan Ketiga, Kencana Prenada Media Group, Jakarta

Hasibuan, Malayu S.P, 2006, Manajemen Sumber Daya Manusia, Cetakan Kedelapan, PT. Bumi Aksara, Jakarta
Hadi Poerwono, 2002, Personel Manajemen Prestasi, Yogyakarta: PEPF-UGM J.Soedarsono, 2007 Pengantar Ekonomi perusahaan, Jakarta : Gramedia Pustaka Utama.

Kepmen Pendidikan dan Kebudayaan Republik Indonesia Nomor 107 Tahun 2013 Tentang Tunjangan Kinerja Bagi Pegawai di Lingkungan 